\title{
MULTI-CRITERIA TECHNOLOGIES FOR MANAGERIAL DECISIONS SYSTEM ANALYSIS
}

\author{
Anatolii Nykyforov ${ }^{1}$, Olena Sushchenko ${ }^{2}$, Mariana Petrova ${ }^{3}$, Nataliia Pohuda ${ }^{4}$ \\ ${ }^{1}$ Kyiv National Economic University named after. V. Getman, Kyiv, Ukraine \\ ${ }^{2,}{ }^{4}$ Simon Kuznets Kharkiv National University of Economics, Kharkiv, Ukraine \\ ${ }^{3}$ St. Cyril and St. Methodius University of Veliko Tarnovo, Veliko Tarnovo, Bulgaria \\ e-mails: ${ }^{1}$ ntid@ukr.net, ${ }^{2} h e l e n . s u s h c h e n k o @ g m a i l . c o m,{ }^{3}$ m.petrova@ts.uni-vt.bg, ${ }^{4}$ nvpoguda@gmail.com
}

Received: 19 December 2020; Accepted: 20 March 2021 Published: 01 May 2021

\begin{abstract}
The article is devoted to the systems analysis technologies application in the sphere of managerial decisions selection in economic growth based performance criteria using different optimality principles. The modern practice of public administration faces the problem of choosing a solution based on a few or multiple criteria in conditions of economic growth. The scientific problem of new systems analysis technologies workability that make it possible to justify managerial decisions using several optimality principles is actualized. The developing a methodology for substantiating managerial decisions of public authorities and local self-government, which could be used by both bodies, is grounded. Conditions of uncertainty in economic growth arise due to the influence of uncontrollable factors on the effectiveness of managerial decisions is noted. The use of the principles of optimism, pessimism, guaranteed results, guaranteed losses, minimax risk (Savage principle) for the systematic justification of managerial decisions is proposed. The use of multicriteria models in economic growth enables to reasonably choose the optimal solution is grounded. Multi-criteria optimization as a system analysis technology for the most effective choice of project under uncertainty is used. An example of optimal choice of local authorities for the project of public-private partnership in the sphere of investment in infrastructure development as an important area of economic growth is given.
\end{abstract}

Keywords: principle, optimality, multi-criteria, managerial decision, economic growth.

JEL classification: M37, Z32, Z39

Citation:

Nykyforov, A., Sushchenko, O., Petrova, M., Pohuda, N. (2021). Multi-Criteria Technologies for Managerial Decisions System Analysis. Access to science, business, innovation in digital economy, ACCESS Press, 2(2): 150-161. https://doi.org/10.46656/access.2021.2.2(3)

\section{INTRODUCTION}

The development of information technology and communications significantly increases competition in all forms of manifestation, which is a common factor of uncertainty in economic conditions. General trends in the uncertainty of the economic environment are exacerbated in Ukraine due to the incompleteness of market transformation processes in the economy, instability in politics and social life. At all hierarchical levels of the economic system, these processes create an additional complication of economic growth. Therefore, developing a methodology for substantiating managerial decisions (MD) of public authorities and local selfgovernment in the face of economic growth, which could be used by both public administration and local self-government bodies, becomes very relevant for economic science in Ukraine. 
This problem becomes especially relevant in the context of decentralization of authority, with the transition to the principles of public administration, when significant financial resources for investment purposes are transferred to local communities. Thus, according to a survey conducted by the National Agency of Ukraine for Civil Service within the Council Europe project, about $70 \%$ of respondents from local communities in all regions claimed that the priority of local governments was infrastructure investment ${ }^{1}$. In particular, in 2020, UAH 73 billion was allocated for road repair, maintenance and reconstruction alone (Akhmedova, 2014). Investment projects in social infrastructure do not have a direct economic effect, but can stimulate the economic growth of each country. We support the opinion of the World Bank experts, who note that the effect of such projects arises as a result of synergistic and multiplicative manifestations of different impacts on the economy (economic, social, environmental and other effects) ${ }^{2}$. So, the modern practice of public administration faces the problem of choosing a solution based on a few or multiple criteria in conditions of economic growth. This requires the scientific development of new systems analysis technologies that make it possible to justify MD using several optimality principles.

\section{Brief literature review}

The theoretical basis taking into account the uncertainty in management decisions developed in the writings of the founders of this scientific direction F. Knight (1921) and G. Simon (1976). Due to L. Zade's research, uncertainty is no longer regarded as an external obstacle to managerial decision-making, but is interpreted as its integral characteristic of the functioning of economic systems (Baturshin et al, 2007; Vinokurov, 2020; Kolesnichenko, 2020; Shmygol et al, 2020; Menshikov et al, 2020; Komarova et al, 2021; Koval et al, 2020).

In order to evaluate the effectiveness of managerial decisions that are made at the stage of substantiation of the feasibility of their implementation, it is proposed to use deterministic and probabilistic models in the economic literature (Trunina et al, 2018; Hlibko, 2020; Radukanov, 2017). The use of a deterministic approach implies that the expectations should have a clear interpretation and accurate estimate. This approach leads to significant limitations of its application in the conditions of uncertainty and unpredictability of the environment (Yankovyi et al, 2019).

\subsection{The purpose of the paper}

Most widely, the scientific literature highlights one of the possible ways of solving this problem, which is to improve the methodology for predicting and using probabilistic models. However, the use of these models is complicated by the uncertainty of the factors that characterize the environment. In practice, this leads to a

\footnotetext{
${ }^{1}$ Advertising and sales promotion. The essence of advertising and its main features, http://megalektsii.ru/s56216t1.html.

${ }^{2}$ National Agency of Ukraine for Civil Service, 2020. Center.gov.ua, URL: https://bit.ly/3kwZKWK
} 
decrease in the reliability of probability models. Given the shortcomings of deterministic and probabilistic models, the authors propose to adapt the theory of game theory to select optimal MD.

\subsubsection{Results and discussion}

When deciding on the feasibility of implementing MD, it is necessary to take into account environmental factors that are uncontrollable, and factors that can be influenced by the state and economic entities, i.e. controllable. Controllable factors have financial, logistical and organizational content. It is assumed that the adjustment of the controllable factors is intended to maximize the effectiveness of the MD in the context of economic growth.

Denote the possible variants of MD that are aimed at achieving the optimum result by $X_{j}$. For local communities, for example, such MD can be highway reconstruction projects, capital reconstruction of schools, and building sewage treatment plants. These MDs are alternative. A set of these alternatives will look like:

$$
X=\left\{X_{j}\right\}, j=\overline{1, m}
$$

Then the area of choice of optimal MD is determined by the influence of uncontrollable factors. Unmanaged factors (Yi) include macroeconomic economic conditions, foreign economic factors, social, environmental, etc. We denote the set of uncontrollable factors by:

$$
Y=\left\{Y_{i}\right\}, i=\overline{1, n}
$$

The performance evaluation of the MD is performed using criterion (E). Performance criteria can be, in our example, indicators of economic, social, environmental performance. According to Radukanov (2014), efficiency has different manifestations and on this basis are distinguished: resource efficiency, cost efficiency, market efficiency, social efficiency, etc. In this case, the performance can be estimated using absolute or relative indicators (efficiency). Absolute metrics are defined as the difference between the result and the cost of resources to achieve that result. Absolute metrics were named effect. A prerequisite for their application is the uniformity of units of outcome and cost. Relative metrics are determined by dividing the result by the amount of resources expended to achieve that result. Relative metrics can be used for both the same and different units of numerator and denominator to achieve this result. Therefore, it is advisable to use them in systematic analysis of different MDs. Therefore, the criterion of performance is the relative indicator - efficiency.

To evaluate the performance of MD, economic efficiency indicators are most often used, which allow them to carry out a comparative analysis, namely: internal rate of return, coefficient of profit-cost, payback period of investments. In quantitative terms, the impact of each of the uncontrolled factors $\left(\mathrm{Y}_{\mathrm{i}}\right)$ on the 
performance of any MD $\left(\mathrm{X}_{\mathrm{j}}\right)$ will be different. The dependence of the metric used as a performance criterion on alternatives and uncontrollable factors is:

$$
E=E(X, Y)
$$

Provided that alternatives to $\mathrm{X}$ and $\mathrm{Y}$ factors are discrete, an efficiency matrix is formed:

$$
\|E(X, Y)\|
$$

Matrix 4 allows us to determine the best variant of MD $\left(x^{0} \in X\right)$ using one of the principles of optimality. Such principles may be: maximum efficiency (optimistic principle), minimum efficiency (pessimistic principle), guaranteed result principle or others. Several principles can be used to systematically analyze MD's performance and select the best solution:

$$
G=\left\{g_{l}\right\}, l=\overline{1, L}
$$

Each of the principles of optimality generally leads to different conclusions about the effectiveness of MD. The following two situations are possible:

1. The results of using each principle of optimality lead to the choice of the same MD,

$$
x_{1}\left(q_{1}\right)=x_{2}\left(q_{2}\right)=\ldots=x_{n}\left(q_{n}\right)
$$

2. The optimal MDs that are determined when applying different principles are different, that is:

$$
x_{1}\left(q_{1}\right) \neq x_{2}\left(q_{2}\right) \neq \ldots \neq x_{n}\left(q_{n}\right)
$$

In situations where the optimal MDs by all principles do not overlap, there is a problem of determining the final MDs, which is adopted for implementation on the basis of systematic analysis of the multi-criterion efficiency model.

Consider an example of choosing the optimal MD based on an assessment of the cost-effectiveness of public-private partnership (PPP) projects under uncertainty using several optimality principles. Suppose that four PPP projects $\left(x_{1}, x_{2}, x_{3}, x_{4}\right)$ have been submitted for the competition, for which the basic principles of optimality are applied: optimism; pessimism; guaranteed result; guaranteed losses; Savage principle. Creating a model for choosing the optimal MD based on game theory should start with building an efficiency matrix. The most time-consuming and responsible step in applying game models to determine optimal MD is to economically evaluate the metrics on which the efficiency matrix is built, because inaccurate estimates in the efficiency matrix cannot be offset by any computational methods and usually lead to an erroneous result. 
When constructing the efficiency matrix, it is assumed that uncontrollable factors $\left(y_{1} \ldots y_{n}\right)$ affect the efficiency of MD simultaneously, but in each $\mathrm{y}_{i}$ the influence of the corresponding uncontrolled factor is preferred. The predominant influence of factor $1\left(y_{l}\right)$ on the PPP project efficiency by number $1\left(x_{l}\right)$ is estimated by the efficiency of $E_{11}$, the predominant influence of factor $2\left(y_{2}\right)$ on the efficiency of project 1 $\left(x_{1}\right)$ by the magnitude of $\mathrm{E}_{12}$, etc. (Table 1 ).

Table 1. Efficiency matrix

\begin{tabular}{ccccc}
\hline $\mathrm{x}$ & & \multicolumn{3}{c}{$\mathrm{y}$} \\
\hline & $\mathrm{y}_{1}$ & $\mathrm{y}_{2}$ & $\ldots$ & $\mathrm{y}_{\mathrm{n}}$ \\
$\mathrm{x}_{1}$ & $\mathrm{E}_{11}$ & $\mathrm{E}_{12}$ & $\ldots$ & $\mathrm{E}_{1 \mathrm{n}}$ \\
$\mathrm{x}_{2}$ & $\mathrm{E}_{21}$ & $\mathrm{E}_{22}$ & $\ldots$ & $\mathrm{E}_{2 \mathrm{n}}$ \\
$\ldots$ & $\ldots$ & $\ldots$ & $\ldots$ & $\ldots$ \\
$\mathrm{x}_{\mathrm{m}}$ & $\mathrm{E}_{\mathrm{m} 1}$ & $\mathrm{E}_{\mathrm{m} 2}$ & $\ldots$ & $\mathrm{E}_{\mathrm{mn}}$ \\
\hline
\end{tabular}

On the basis of the principle of optimism, the upper limit of efficiency of PPP projects is determined in the conditions of uncertainty of the environment, which allows choosing the optimal project (Table 2):

$$
E_{\text {opt }}=\max \max E(x, y)
$$

$$
x \in X, y \in Y
$$

Table 2. Optimism principle efficiency matrix

\begin{tabular}{cccccc}
\hline $\mathrm{x}$ & \multicolumn{2}{c}{$\mathrm{y}$} & & $\max \mathrm{E}$ \\
\hline & $\mathrm{y}_{1}$ & $\mathrm{y}_{2}$ & $\ldots$ & $\mathrm{y}_{\mathrm{n}}$ & \\
$\mathrm{x}_{1}$ & $\mathrm{E}_{11}$ & $\mathrm{E}_{12}$ & $\ldots$ & $\mathrm{E}_{1 \mathrm{n}}$ & $\mathrm{E}_{1 \max }$ \\
$\mathrm{x}_{2}$ & $\mathrm{E}_{21}$ & $\mathrm{E}_{22}$ & $\ldots$ & $\mathrm{E}_{2 \mathrm{n}}$ & $\mathrm{E}_{2 \max }$ \\
$\ldots$ & $\ldots$ & $\ldots$ & $\ldots$ & $\ldots$ & $\ldots$ \\
$\mathrm{x}_{\mathrm{m}}$ & $\mathrm{E}_{\mathrm{m} 1}$ & $\mathrm{E}_{\mathrm{m} 2}$ & $\ldots$ & $\mathrm{E}_{\mathrm{mn}}$ & $\mathrm{E}_{\operatorname{mmax}}$ \\
\hline
\end{tabular}

The principle of pessimism implies that uncontrollable factors act in the most unfavorable way and those that are controllable are misused. This principle sets the bottom line for the effectiveness of PPP projects that are selected for implementation under the influence of uncontrollable factors. The principle of pessimism is written in the form (Table 3):

$$
\begin{aligned}
& E_{p e s}=\min \min E(x, y) \\
& x \in X, y \in Y
\end{aligned}
$$


Table 3. Pessimism principle efficiency matrix

\begin{tabular}{cccccc}
\hline $\mathrm{x}$ & \multicolumn{2}{c}{$\mathrm{y}$} & & $\min \mathrm{E}$ \\
\hline & $\mathrm{y}_{1}$ & $\mathrm{y}_{2}$ & $\ldots$ & $\mathrm{y}_{\mathrm{n}}$ & \\
$\mathrm{x}_{1}$ & $\mathrm{E}_{11}$ & $\mathrm{E}_{12}$ & $\ldots$ & $\mathrm{E}_{1 \mathrm{n}}$ & $\mathrm{E}_{1 \min }$ \\
$\mathrm{x}_{2}$ & $\mathrm{E}_{21}$ & $\mathrm{E}_{22}$ & $\ldots$ & $\mathrm{E}_{2 \mathrm{n}}$ & $\mathrm{E}_{2 \min }$ \\
$\ldots$ & $\ldots$ & $\ldots$ & $\ldots$ & $\ldots$ & $\ldots$ \\
$\mathrm{x}_{\mathrm{m}}$ & $\mathrm{E}_{\mathrm{m} 1}$ & $\mathrm{E}_{\mathrm{m} 2}$ & $\ldots$ & $\mathrm{E}_{\mathrm{mn}}$ & $\mathrm{E}_{\mathrm{mmin}}$ \\
\hline
\end{tabular}

The Guaranteed Result principle shows what kind of guaranteed result we can get in the presence of uncontrollable factors that act in the most unfavorable way. This principle is written in the form (Table 4):

$$
\begin{aligned}
& E g=\min \min E_{g}(x, y) \\
& x \in X, y \in Y
\end{aligned}
$$

\begin{tabular}{|c|c|c|c|c|c|}
\hline \multirow[t]{2}{*}{$\mathrm{x}$} & \multicolumn{4}{|c|}{$\mathrm{y}$} & \multirow[t]{2}{*}{$\min E_{g}$} \\
\hline & $\mathrm{y}_{1}$ & $\mathrm{y}_{2}$ & $\ldots$ & $\mathrm{y}_{\mathrm{n}}$ & \\
\hline $\mathrm{X}_{1}$ & $\mathrm{E}_{11}$ & $\mathrm{E}_{12}$ & $\ldots$ & $\mathrm{E}_{1 \mathrm{n}}$ & $\mathrm{E}_{1 \mathrm{~g} \min }$ \\
\hline $\mathrm{x}_{2}$ & $\mathrm{E}_{21}$ & $\mathrm{E}_{22}$ & $\ldots$ & $\mathrm{E}_{2 \mathrm{n}}$ & $\mathrm{E}_{2 \mathrm{~g} \min }$ \\
\hline$\ldots$ & $\ldots$ & $\ldots$ & $\ldots$ & $\ldots$ & $\ldots$ \\
\hline $\mathrm{X}_{\mathrm{m}}$ & $\mathrm{E}_{\mathrm{m} 1}$ & $\mathrm{E}_{\mathrm{m} 2}$ & $\ldots$ & $\mathrm{E}_{\mathrm{mn}}$ & $\mathrm{E}_{\mathrm{mg} \min }$ \\
\hline
\end{tabular}

Table 4. The guaranteed result principle efficiency matrix

The Savage principle is used to determine the minimum amount of damage (actual or potential) caused by the influence of uncontrollable factors (Table 5):

$$
\begin{aligned}
& E_{s}=\min \max Y\left(x, y^{\prime}\right) \\
& x \in X, y \in Y
\end{aligned}
$$

Table 5. Savage principle damage matrix

\begin{tabular}{cccccc}
\hline $\mathrm{x}$ & & & $\mathrm{y}$ & & $\max \mathrm{Y}$ \\
\hline & $\mathrm{y}_{1}$ & $\mathrm{y}_{2}$ & $\ldots$ & $\mathrm{y}_{\mathrm{n}}$ & \\
$\mathrm{x}_{1}$ & $\mathrm{E}_{11}$ & $\mathrm{E}_{12}$ & $\ldots$ & $\mathrm{E}_{1 \mathrm{~m}}$ & $\mathrm{Y}_{1 \max }$ \\
$\mathrm{x}_{2}$ & $\mathrm{E}_{21}$ & $\mathrm{E}_{22}$ & $\ldots$ & $\mathrm{E}_{2 \mathrm{~m}}$ & $\mathrm{Y}_{2 \max }$ \\
$\ldots$ & $\ldots$ & $\ldots$ & $\ldots$ & $\ldots$ & $\ldots$ \\
$\mathrm{X}_{\mathrm{n}}$ & $\mathrm{E}_{\mathrm{n} 1}$ & $\mathrm{E}_{\mathrm{n} 2}$ & $\ldots$ & $\mathrm{E}_{\mathrm{nm}}$ & $\mathrm{E}_{\mathrm{nmax}}$ \\
\hline
\end{tabular}

where $\mathrm{y}\left(\mathrm{x}, \mathrm{y}^{\prime}\right)=\max \mathrm{E}\left(\mathrm{x}, \mathrm{y}^{\prime}\right)-\mathrm{E}\left(\mathrm{x}, \mathrm{y}^{\prime}\right)-$ is the amount of damage caused by the choice of a suboptimal PPP project; 
$y^{\prime}-$ is a fixed value of $y$.

The principle of guaranteed losses determines the deviation (loss) of efficiency caused by the action of uncontrollable factors. This principle is formulated as follows (Table 6):

Table 6. Guaranteed loss principle damage matrix

\begin{tabular}{|c|c|c|c|c|c|}
\hline \multirow[t]{2}{*}{$x$} & \multicolumn{4}{|c|}{$\mathrm{y}$} & \multirow[t]{2}{*}{$\operatorname{maxP}$} \\
\hline & $\mathrm{y}_{1}$ & $\mathrm{y}_{2}$ & $\ldots$ & $\mathrm{y}_{\mathrm{n}}$ & \\
\hline $\mathrm{x}_{1}$ & $P_{11}$ & $P_{12}$ & $\ldots$ & $P_{1 \mathrm{~m}}$ & $P_{1 \max }$ \\
\hline $\mathrm{x}_{2}$ & $P_{21}$ & $P_{22}$ & $\ldots$ & $P_{2 \mathrm{~m}}$ & $P_{2 \max }$ \\
\hline$\ldots$ & $\ldots$ & $\ldots$ & $\ldots$ & $\ldots$ & $\ldots$ \\
\hline$X_{n}$ & $P_{\mathrm{n} 1}$ & $P_{\mathrm{n} 2}$ & $\ldots$ & $P_{\mathrm{nm}}$ & $P_{\mathrm{nmax}}$ \\
\hline
\end{tabular}

$P_{g}=\operatorname{minmax} P\left(\mathrm{x}^{\prime}, \mathrm{y}\right)$

$x \in X, y \in Y$

$P\left(\mathrm{x}^{\prime}, \mathrm{y}\right)=E\left(\mathrm{x}^{\prime}, \mathrm{y}\right)_{\text {max }}-E(x, y)$,

where $\mathrm{x}^{\prime}-$ is a fixed value of $\mathrm{x}$.

To test the multi-criteria MD system analysis technology based on the use of game models, let's consider our example. Suppose there are four public-private partnership (PPP) projects $\left(\mathrm{x}_{1}, \mathrm{x}_{2}, \mathrm{x}_{3}, \mathrm{x}_{4}\right)$ proposed for competition by state or local government: $\mathrm{x}_{1}$ - highway reconstruction, $\mathrm{x}_{2}$ - capital reconstruction of schools, stadium construction, building sewage treatment plants. Effectiveness of these projects depends largely on the effects of uncontrollable factors: $\mathrm{y}_{1}$ - macroeconomic - population savings; $\mathrm{y}_{2}$ - foreign trade - the ratio of prices for domestic and similar imported goods; $\mathrm{y}_{3}$ - social - changes in demand in the sectoral markets (due to changes in the preferences of the population). In order to fill the efficiency matrices, the factors $\left(\mathrm{y}_{1}, \mathrm{y}_{2}, \mathrm{y}_{3}\right.$, $\mathrm{y}_{4}$ ) value must be quantified and reduced to a comparative form. This reduction is performed via standardization and transforming all indicators into a score using a single scale. In our example, the scale has a range from 1 to 15 points. An example of such a methodology is the UN recommendations for determining the human development index ${ }^{1}$. The calculation results are given in y (Table 7).

We determine the optimal PPP according to the criterion of economic efficiency according to the above principles of optimality:

1. on the principle of optimism:

$$
x_{o p t}^{0}=x_{2}, E_{o n n}=12 \text { units; }
$$

\footnotetext{
${ }^{1}$ UNDP, United Nations Development Programme, 2020. URL: https://bit.ly/3pvBWpM
} 
Table 7. PPP project efficiency matrix

\begin{tabular}{|c|c|c|c|c|c|}
\hline \multirow[t]{2}{*}{$\mathrm{x}$} & \multicolumn{3}{|c|}{$\mathrm{y}$} & \multirow[t]{2}{*}{$\max E$} & \multirow[t]{2}{*}{$\min E$} \\
\hline & $\mathrm{y}_{1}$ & $\mathrm{y}_{2}$ & $\mathrm{y}_{3}$ & & \\
\hline $\mathrm{x}_{1}$ & 7 & 9 & 5 & 9 & 5 \\
\hline $\mathrm{X}_{2}$ & 2 & 7 & 12 & 12 & 2 \\
\hline $\mathrm{X}_{3}$ & 3 & 8 & 4 & 8 & 3 \\
\hline $\mathrm{X}_{4}$ & 1 & 10 & 6 & 10 & 1 \\
\hline
\end{tabular}

We determine the optimal PPP according to the criterion of economic efficiency according to the above principles of optimality:

2. on the principle of optimism:

$$
x_{o p t}^{0}=x_{2}, E_{\text {onn }}=12 \text { units; }
$$

on the principle of pessimism:

$$
x_{o p t}^{0}=x_{4}, E_{n e c}=1 \text { units; }
$$

on the principle of guaranteed result:

$x_{2}^{0}=x_{1}, E_{2}=5$ units.

Let us find the optimal solution using the Savage principle. To do this, we construct a loss matrix (Table 8) based on a basic efficiency matrix (Table 7). Select the maximum efficiency of PPP projects from the table 7 under the influence of factor $1\left(\mathrm{y}_{1}\right)$. This corresponds to 7 units $\left(\mathrm{E}_{11}\right)$ for the 1 st project $\left(\mathrm{x}_{1}\right)$.

Determine the value of $\left(\mathrm{E}_{11}\right)$ ( 7 units) as a fixed value for factor $\mathrm{u} 1$ and calculate the magnitude of the losses of all projects, compared to the maximum value. The results of the calculations are given in the $1 \mathrm{st}$ column $\left(\mathrm{y}_{1}\right)$ of the Table 8. For different factors $\mathrm{y}_{2}$ and $\mathrm{y}_{3}$ we will carry out similar operations and calculations.

Table 8. PPP project loss matrix

\begin{tabular}{ccccc}
\hline $\mathrm{x}$ & \multicolumn{2}{c}{$\mathrm{y}$} & $\max$ \\
\hline & $\mathrm{y}_{1}$ & $\mathrm{y}_{2}$ & $\mathrm{y}_{3}$ & \\
$\mathrm{x}_{1}$ & 0 & 1 & 7 & 7 \\
$\mathrm{x}_{2}$ & 5 & 3 & 0 & 5 \\
$\mathrm{x}_{3}$ & 4 & 2 & 8 & 8 \\
$\mathrm{x}_{4}$ & 6 & 0 & 6 & 6 \\
\hline
\end{tabular}


According to the Savage principle, the PPP project that corresponds to the minimum amount of losses will be optimal: $x_{c}^{0}=x_{2}, Y_{2}=5$ units.

To apply the principle of guaranteed losses, we construct a loss matrix by choosing from the table 7 the maximum value of PPP projects efficiency under the influence of factors.

For project $\mathrm{x}_{1}-$ it is 9 units $\left(\mathrm{E}_{12}\right)$ under the influence of factor $\mathrm{y}_{2}$. We are able to calculate the magnitude of the losses of all projects, compared to the maximum value. The results of the calculations are given in the 1 st row $\left(\mathrm{x}_{1}\right)$ of the Table 9 .

Table 9. The loss matrix for the PPP projects

\begin{tabular}{ccccc}
\hline $\mathrm{x}$ & \multicolumn{2}{c}{$\mathrm{y}$} & $\max \Pi$ \\
\hline & $\mathrm{y}_{1}$ & $\mathrm{y}_{2}$ & $\mathrm{y}_{3}$ & \\
$\mathrm{x}_{1}$ & 2 & 0 & 4 & 4 \\
$\mathrm{x}_{2}$ & 10 & 5 & 0 & 10 \\
$\mathrm{x}_{3}$ & 5 & 0 & 4 & 5 \\
$\mathrm{x}_{4}$ & 9 & 0 & 4 & 9 \\
\hline
\end{tabular}

Perform the same operations and calculations for projects $\mathrm{x}_{2}, \mathrm{x}_{3}, \mathrm{x}_{4}$.

Let's determine the optimal PPP project based on the principle of guaranteed losses: $x_{2 n}^{0}=x_{1}, \Pi_{2}=4$ units.

The results of the application of different principles are given in Table 10.

In our example, a systematic analysis of the effectiveness of PPP projects submitted to the competition shows that projects № 1 and № 2 should be preferred to select the optimal MD.

Table 10. Optimal PPP projects identified with application of different principles of optimality

\begin{tabular}{cc}
\hline Principle & Optimal projects \\
\hline Optimism principle & $x_{2}$ \\
Pessimism principle & $x_{4}$ \\
Guaranteed result principle & $x_{1}$ \\
Savage principle & $x_{2}$ \\
Guaranteed loss principle & $x_{1}$ \\
\hline
\end{tabular}

Thus, according to different optimality principles, $\mathrm{MD}$ is formed that project № 1 (highway reconstruction) is optimal for implementation on two principles: guaranteed result and guaranteed losses; project № 2 (capital reconstruction of schools) is also based on two principles: optimism (maximum efficiency) and Savage principle (minimax risk). This is also confirmed by the results of a comparative analysis of the cost-effectiveness of the selected projects, since both projects № 1 and № 2 have the same, 
and substantially greater than the other, control over the allocation of efficiency. At the same time, the analysis of the degree of risk of these projects shows that the distribution of efficiency under the influence of uncontrollable factors in project № 2 has a range of fluctuations of efficiency of 2 - 12 units and in project № 1 there are only 5-9 units, so there are certain reasons to conclude that project № 1 is less risky. Thus, the use of multi-criteria models in economic growth enables, for example local authorities, to reasonably choose the optimal solution.

\section{CONCLUSION}

Approbation of models of multi-criteria optimization on an example of a choice of managerial decisions in the context of economic growth gives the grounds to draw the following conclusions:

1. the use of these models increases the validity of decisions, because it is based on qualitative (substantive) and quantitative assessments of socio-economic efficiency of alternative capital investments in infrastructure development;

2. models of multi-criteria optimization allow comparative analysis of qualitatively (substantively) different indicators of alternative capital investments;

3. these models make it possible to take into account and compare any factors influencing managerial decisions in economic growth;

4. the degree of validity, as in the use of any other methods of assessing socio-economic efficiency, depends on the reliability of measuring quantitative parameters and the quality of expert opinions.

\section{Conflict of interests}

The authors declare no conflict of interest.

\section{References}

Advertising and sales promotion. The essence of advertising and its main features. Retrieved August 17, 2020, from http://megalektsii.ru/s56216t1.html.

Akhmedova, O. (2014) The use of simulation methods of teaching future bachelors in tourism services. Donetsk state university of management, V 5, p. 25-30.

Baturshin, I., Kacprzyk, I., Sheremetov, L., Zadeh, L. (2007). Perception-based Date Mining and Decision Making in Economics and Finance, Berlin, Springer-Verlag.

Hlibko, S. (2020). The Issue of Implementation the Guarantees of Entrepreneurship in the Economic Law of Ukraine. Modern problems of the development of law and economics in an innovative society: scientific collection works of the International scientific and practical conference (March 20, 2020). M. Petrova, S. Hlibko, Veliko Tarnovo (Ed.). Publishing House "ACCESS PRESS", 70-75 p. URL: https://access-bg.org/conferences/2020-03-20-velikotarnovo.

Knight, F. (1921). Risk, Uncertainty and Profit, 1-st ed., Boston and New York, Houghhton Mifflin Compani.

Kolesnichenko, O. (2020). New road strategy 2020: how the government plans to "stitch" the whole country with roads. URL: https://bit.ly/2ZMqVFq. 
Komarova V., Selivanova-Fyodorova N., Ruza O., Kaźmierczyk J., Arbidane I. (2021) Modern trends in the economic differences between countries and within them: comparison of the world and the European Union, Entrepreneurship and Sustainability Issues 8(3): 110-121. https://doi.org/10.9770/jesi.2020.8.3(6)

Koval, V., Mikhno, I., Trokhymets, O., Kustrich, L., Vdovenko, N. (2020) Modeling the interaction between environment and the economy considering the impact on ecosystem. E3S Web Conf. 16613002

Mensikovs V., Kokina I., Komarova V., Ruza O., Danilevica A. (2020) Measuring multidimensional poverty within the resource-based approach: a case study of Latgale region, Latvia. Entrepreneurship and Sustainability Issues, Vol. 8, No. 2, pp. 1211-1227. http://doi.org/10.9770/jesi.2020.8.2(72).

National Agency of Ukraine for Civil Service, 2020. Center.gov.ua, URL: https://bit.ly/3kwZKWK

Radukanov, S. (2017). Market risk assessment using expected tail lost (ETL) - peculiarities and application, New Knowledge Journal of Science ISSN 2367-4598 (Online), Academic Publishing House „Talent“ University of Agribusiness and Rural Development - Bulgaria, Volume 6 (№ 5), p. 67 - 76

Radukanov, S. (2014). Study of the resource efficiency of banks in Bulgaria, Annual Doctoral Research Almanac, Vol. 7, D. A. Tsenov Academy of Economics, p. 323-349

Simon, H. (1976). Administrative Behavior. A Stady of Decision-Making Process in Administrative Organizations, 3-d ed., New York, Free Press, London, Collier, Macmillan.

Shmygol, N., Schiavone, F., Trokhymets, O., Pawliszczy, D., Koval, V., Zavgorodniy, R., Vorfolomeiev, A. (2020) Model for assessing and implementing resource-efficient strategy of industry. CEUR Workshop Proceedings 2713 277-294

Trunina, I., Vartanova, O., Sushchenko, O., Onyshchenko, O. (2018). Introducing ERP System as a Condition of Information Security and Accounting System Transformation, International Journal of Engineering \& Technology, 7(4.3) 530-536.

UNDP, United Nations Development Programme, 2020. URL: https://bit.ly/3pvBWpM

Vinokurov, Y. (2020). The road to credit: will the "Great Construction" save Zelensky's economy? URL: https://bit.ly/3mvoOiN.

Yankovyi, O., Goncharov, Yu., Koval, V., Lositska, T. (2019). Optimization of the capital-labor ratio on the basis of production functions in the economic model of production. Naukovyi Visnyk Natsionalnoho Hirnychoho Universytetu 4 (2019) 134-140.

\section{About the authors}

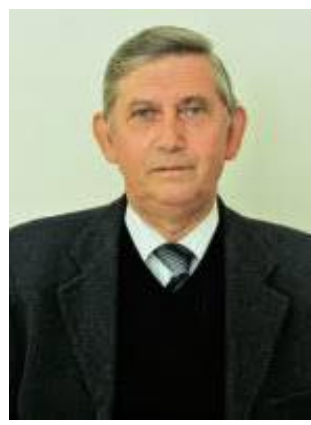

\section{Anatolii NYKYFOROV}

Dr.Sc. (Economics), Professor, Kyiv National Economic University named after. V. Getman, Kyiv, Ukraine. Scientific interests: state regulation of innovation and investment activities, competition policy, intellectual potential of the national economy; innovative economy.

ORCID ID: https://orcid.org/0000-0001-8480-0870

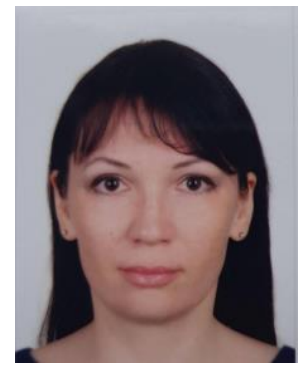

\section{Olena SUSHCHENKO}

Dr.Sc. (Economics), Professor, Simon Kuznets Kharkiv National University of Economics, Kharkiv, Ukraine. Scientific interests: tourism and hospitality, economics and management, international business.

ORCID ID: https://orcid.org/0000-0002-2645-8015 


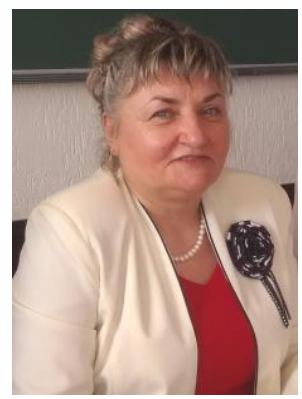

\section{Mariana PETROVA}

Professor, D.Sc in Physics and Mathematics, assoc.prof. St. Cyril and St. Methodius University of Veliko Tarnovo, Bulgaria; Professor Economics and Management in Department of Management, ISMA University, Riga, Latvia. Research interests: management of IT processes, project and services, business administration, modern information systems and innovations, knowledge economy, sustainable development.

ORCID ID: https://orcid.org/0000-0003-1531-4312

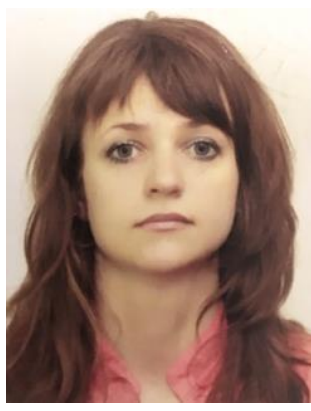

\section{Nataliia POHUDA}

Ph.D. (Economics), Associated Professor, Simon Kuznets Kharkiv National University of Economics, Kharkiv, Ukraine. Scientific interests: institutional problems of tourism activity, institutional aspects of economic development, human development.

ORCID ID: https://orcid.org/0000-0002-8926-9350

Copyright (C) 2020 by author(s) and ACCESS Publishing Press This work is licensed under the Creative Commons Attribution International License (CC BY) 